\title{
Exploring Pronunciation Teaching Practice in Emergency Remote Teaching: Lesson From Indonesian High School Context
}

\author{
Aina Khoirida ${ }^{1,2}$, Endang Setyaningsih ${ }^{1}$, Hasan Zainnuri ${ }^{1}$ \\ ${ }^{1}$ Universitas Sebelas Maret \\ 2Email: ainakhoirida@student.uns.ac.id
}

\begin{abstract}
Regardless of its importance, pronunciation practice received a small portion in EFL teaching. This issue has attracted researchers to investigate how pronunciation practice is conducted in the EFL setting and what challenges are there. The results of the investigations have provided useful insights into what happens in the EFL classrooms. However, with the global pandemic outbreak that forced massive migration to emergency remote teaching (ERT), it remains unclear how pronunciation practice is carried out. This exploratory study attempts to shed light on the matter. It aims to portray the pronunciation practice during ERT and identify the challenges faced by the teachers. To limit the scope of the study, the researchers focused the investigation only on pronunciation accuracy. Data were collected through document analysis, nonparticipatory observation, questionnaire, and in-depth interview after gaining consent from two senior high schools English teachers in Indonesia. The collected data were then analyzed using the interactive model of analysis. This study reveals that during ERT, pronunciation practice received a small portion of attention, as earlier studies have found. The average time allocated is $10 \%$ of the total duration of learning. Most of the accuracy training was carried out with a similar pattern of activities, i.e., read aloud, listen-and-repeat, and teachers' corrective feedback as the response of the student's errors. Presented in ERT, pronunciation accuracy training experienced several problems, and the most prominent is related to the internet connection. A poor internet connection can be disastrous for accuracy training as implementing synchronous learning or uploading and downloading audio/video requires a good and strong internet connection. Another problem is the lack of students' engagement to study due to the difference in sensation and excitement with face-to-face learning. These imply that adequate preparation is needed in applying pronunciation accuracy instruction, apart from the material itself.
\end{abstract}

Keywords: Emergency Remote Teaching; pronunciation accuracy; pronunciation practice 


\section{INTRODUCTION}

Pronunciation is one of the speaking skills aspects that received the least attention in English Language Teaching (ELT) compared to grammar and vocabulary. As Brown (1991) and Foote et al. (2016) corpus-based evidence of actual teacher behaviour with respect to the teaching of second language (L2 found, pronunciation teaching received a small concentration that is not more than $8 \%$ of the total duration in the English teaching process if not ignored. It is contrary to the fact that being able to pronounce English words well is crucial in speaking since it will make it easy for the interlocutors to understand and get the point of the message (Kelly 2002). The research conducted by Pennington and Richards (1986) and Celce-Murcia, Brinton, and Goodwin (1996) reported that pronunciation ability should be mastered by the students and taught by the teachers. Thomson and Derwing (2015)despite reports of significant improvement in many studies. Possible explanations for divergent outcomes include learner individual differences, goals and foci of instruction, type and duration of instructional input, and assessment procedures. After identifying key concepts, we survey 75 L2 pronunciation studies, particularly their methods and results. Despite a move towards emphasizing speech intelligibility and comprehensibility, most research surveyed promoted native-like pronunciation as the target. Although most studies entailed classroom instruction, many featured Computer Assisted Pronunciation Teaching (CAPT argued that pronunciation instruction in the teaching and learning process would be improved by pronunciation instruction. By practicing pronunciation, it will train students' pronunciation to be more understandable. Since pronunciation ability is limited to communicating with the teachers in the learning activity and the others' language speakers (Yoshida 2016).

The significant topics of interest in pronunciation teaching in the past three decades were intelligibility, supra-segmental, and lingua franca. So far from that, in the nativeness principle in the 1960s, the target sound system of the majority English as Foreign Language (EFL) and English as Second Language (ESL) pronunciation teaching programs was nativelike mastery. However, in the 1990s, the aims of pronunciation teaching programs were changing from native-like to intelligible speech because nativelike pronunciation was not possible for all English learners, especially English as Foreign Language (EFL) learners (Abbas Pourhossein Gilakjani 2017).

In later years, the focus of teaching pronunciation has moved from segmental features to suprasegmental features (Derwing and Munro 2005; Pennington and Richards 1986). The researchers agree that factors such as stress, intonation, and sounds have more significance in accomplishing good pronunciation. Derwing, Munro, and Wiebe (1998) found that students with suprasegmental instruction claimed a reasonably good improvement in comprehension and fluency. Thus, suprasegmental teaching had a significant influence on speakers when transferring their learning to spontaneous speech.

The readiness and belief of the English teachers related to pronunciation play a crucial role in teaching practice. Researchers have reported that the lack of motivation and knowledge is the main reason for the neglect of pronunciation teaching (Abdolmanafi- 
Rokni, Jalal, and Rokni 2013; Baker and Murphy 2011; Kelly 2002). The teachers were unsure about their English pronunciation, so they did not teach it to their students. Moreover, the other reason is the teachers' uncertainty in managing pronunciation materials in the classroom, including their technique (Couper 2016). Foote et al. (2016)corpus-based evidence of actual teacher behaviour with respect to the teaching of second language (L2 described the teachers in their study as mainly implementing two methods to teach their students pronunciation. Those are corrective feedback and listen-and-repeat as the response to the student's errors.

In the context of Emergency Remote Teaching (ERT), research about pronunciation teaching is still under-researched. ERT refers to the government policy in the pandemic of Coronavirus Disease-19 (Covid-19). ERT and online courses are similar, which means virtual classes, and there is no face-toface (F2F) interaction. Hodges and Fowler (2020) showed the definition of ERT as a sudden educational procedure to keep conducting the educational process in the middle of lockdown. Nevertheless, ERT still has problems and is challenging for educators and learners (Mardiah 2020). The teachers were unsure in managing the materials and evaluations; meanwhile, the students lacked engagement and motivation since the different excitement in the classrooms. Meanwhile, 70\% of undergraduates EFL learners in Hazaymeh's (2021) research showed a positive attitude about the innovative design and structure of teaching English speaking materials provided electronically to them.
The practice of pronunciation teaching in an ERT setting changed correspondingly as previous researchers found that pronunciation in the F2F has been ignored, even more so in the ERT context since the teachers are still confused with technology. Before there was ERT, researchers found that many teachers worldwide applied distance learning with technologybased. For example, the teachers in Cunningham's (2015) research used video conferences by Adobe Connect to teach their students pronunciation. Similarly, the teachers who participated in Abbas Pourhosein Gilakjani et al.'s (2019) research showed positive attitudes to using computer pronunciation software, Pronunciation Power 2. At the same time, Martin (2020) implemented Computer Assisted Pronunciation Training (CAPT). This tool was designed to be used in F2F teaching and can be used in ERT classrooms. Using technology, teachers can create an interactive atmosphere that helps make it easier for them to get maximum competence in teaching practice.

The main objective of this study was to investigate the accuracy aspect of pronunciation practice in ERT contexts. Although there have been researches about pronunciation teaching, there is still a lack of a record on the ERT context, which is a new term due to the global pandemic. Therefore, the data were gathered from multiple techniques, observations (documents and classrooms), questionnaires, and interviews. The study involved two senior high school English teachers in Central Java Province, Indonesia. This research seeks to address the following questions: (1) How is pronunciation treated in ERT English lessons? and (2) What are the challenges of pronunciation teaching practice in an ERT English classroom? 


\section{METHOD}

\section{Procedure}

This exploratory case study was conducted for two months, and data were collected through lesson plan documents analysis, non-participatory classroom observation, questionnaires, and indepth interviews. The analysis of the lesson plans was guided by a pre-developed checklist to find out whether or not the teachers plan pronunciation accuracy teaching and what strategies were going to be used. The observation was recorded in a semistructured field note in which a set of checklists on suprasegmental features (intonation, stress, and sounds) and extended notes are provided. The questionnaire consisted of three sections which each section consisted of a four-point Likert scale and open-ended questions about teachers' preferences in using techniques to teach pronunciation. For example, the first section asked about teaching rising and falling intonation, the second section asked about teaching word and sentence stress. The third section asked about vowel and consonant sounds. At the same time, the interview was implemented to gain more profound information and data about the teachers' motivation in teaching accuracy of pronunciation and the techniques used.

\section{Participants}

The participants were two English teachers, one female and one male, from a public senior high school in Indonesia. In this study, Joy will be used as the pseudonym of the female participant and Mark for the male participant to protect participants' identity and anonymity of information. The background profile of Joy and Mark is shown in Table 1.

Table 1

\section{Profile of the Participants}

\begin{tabular}{|l|l|l|}
\multicolumn{1}{|c|}{$\begin{array}{c}\text { Participant } \\
\text { (Pseudonym) }\end{array}$} & \multicolumn{1}{|c|}{ Joy } & \multicolumn{1}{c|}{ Mark } \\
\hline Designation & Teacher & Teacher \\
\hline Subject taught & English (Literature) & English (Literature) \\
\hline $\begin{array}{l}\text { Teaching hours (per } \\
\text { week) }\end{array}$ & 24 & 8 \\
\hline Age & 46 & 46 \\
\hline Gender & F & M \\
\hline $\begin{array}{l}\text { Highest educational } \\
\text { qualification }\end{array}$ & MA & BA \\
\hline Years of experience & 23 & 22 \\
\hline Department & $\begin{array}{l}\text { English Education; } \\
\text { Education } \\
\text { Management }\end{array}$ & English Education \\
\hline
\end{tabular}

\section{Data Analysis}

The accumulated data were analyzed using Miles, Huberman, and Saldaña’s (2014) model in analyzing the qualitative data, which consisted of three steps; data condensation, data display, and conclusion and verification. The first is data condensation to select, simplify, and transform the data. In this step, the researcher converted and reduced raw data by selecting and sorting the collected data from the observation sheet, questionnaire data, and interview transcription. The second data analysis step is data display, aiming to make the data arranged into available and attainable form. The data which have been reduced and sorted were displayed in this step. The last step is conclusion and verification. In this step, the findings of the study were drawn from the accumulated and formulated data. 
FINDINGS AND DISCUSSION

\section{Pronunciation Teaching During ERT}

This study's primary data deal with the teachers' strategies and preferences in designing and implementing pronunciation training for their students during ERT. The data analysis result collected from the document and classroom observation showed that pronunciation is taught in the ERT classroom. The classroom observation was held for ten meetings or five weeks in Joy and Mark's classes. The observation data are shown in Table 2 and Table 3.

Table 2

Teachers' Plans in Pronunciation Practice

\begin{tabular}{|l|l|l|}
\hline \multicolumn{1}{|c|}{ Indicators } & \multicolumn{1}{c|}{ Joy } & \multicolumn{1}{c|}{ Mark } \\
\hline Syllabi & & $\checkmark$ \\
\hline Intonation & $\sqrt{ }$ & $\checkmark$ \\
\hline Stress & $\sqrt{ }$ & $\sqrt{ }$ \\
\hline Sound & $\sqrt{ }$ & Listen and read \\
\hline Technique used & Reading & $\sqrt{ }$ \\
\hline $\begin{array}{l}\text { Pronunciation } \\
\text { evaluation }\end{array}$ & $\sqrt{ }$ & $\sqrt{ }$ \\
\hline Lesson Plans & $\sqrt{ }$ & $\sqrt{ }$ \\
\hline Intonation & $\sqrt{ }$ & Listen and read \\
\hline Stress & $\sqrt{ }$ & $\sqrt{ }$ \\
\hline Sound & Reading & \\
\hline Technique used & & \\
\hline Pronunciation & & \\
\hline
\end{tabular}

Table 2 shows that Joy and Mark planned to teach and evaluate pronunciation in their classes. The strategies they chose were tailored to meet the basic competence and objectives of the materials that would be taught.

Table 3

Pronunciation Practice in the Classrooms

\begin{tabular}{|c|c|c|c|c|}
\hline \multirow{2}{*}{$\begin{array}{l}\text { Obser- } \\
\text { vations }\end{array}$} & \multicolumn{2}{|c|}{ Joy } & \multicolumn{2}{|c|}{ Mark } \\
\hline & Duration & Strategy & Duration & Strategy \\
\hline Meeting 1 & $70 \%$ & $\begin{array}{l}\text { Listen and } \\
\text { repeat, } \\
\text { Corrective } \\
\text { feedback }\end{array}$ & $0 \%$ & - \\
\hline Meeting 2 & $67 \%$ & $\begin{array}{l}\text { Listen and } \\
\text { repeat, } \\
\text { Corrective } \\
\text { feedback }\end{array}$ & $0 \%$ & - \\
\hline Meeting 3 & $0 \%$ & - & $24 \%$ & $\begin{array}{l}\text { Corrective } \\
\text { feedback, } \\
\text { Minimal pair }\end{array}$ \\
\hline Meeting 4 & $0 \%$ & - & $15 \%$ & $\begin{array}{l}\text { Corrective } \\
\text { feedback, } \\
\text { Minimal pair }\end{array}$ \\
\hline Meeting 5 & $0 \%$ & - & $0 \%$ & - \\
\hline Meeting 6 & $0 \%$ & - & $0 \%$ & - \\
\hline Meeting 7 & $7 \%$ & $\begin{array}{l}\text { Reading, } \\
\text { Corrective } \\
\text { feedback, } \\
\text { Minimal pair }\end{array}$ & $11 \%$ & $\begin{array}{l}\text { Corrective } \\
\text { feedback }\end{array}$ \\
\hline Meeting 8 & $13 \%$ & $\begin{array}{l}\text { Reading, } \\
\text { Corrective } \\
\text { feedback }\end{array}$ & $0 \%$ & - \\
\hline Meeting 9 & $0 \%$ & - & $0 \%$ & - \\
\hline Meeting 10 & $0 \%$ & - & $0 \%$ & - \\
\hline
\end{tabular}


Table 3 shows the duration and the applied strategies by Joy and Mark during the teaching and learning process in ERT settings. It can be seen that both Joy and Mark did not always teach pronunciation in every meeting. In addition, Joy and Mark did not apply the strategy they planned as stated in the syllabi and lesson plans yet still taught pronunciation using their preferred approach.

The first findings show the duration of pronunciation instruction in ERT classes. Observations reveal that pronunciation accuracy practice in Joy and Mark's classes is not taught for every meeting. In Joy's classes, pronunciation instruction was observed in the first, second, seventh, and eighth meetings, with a total portion was $16 \%$. While in Mark's classes, among ten observation meetings, pronunciation teaching duration was $5 \%$ which was found in the third, fourth, and seventh meetings. So, the average duration of pronunciation accuracy practice was $11 \%$ of the total learning time.

These results match those observed in earlier studies. For example, Foote et al. (2016)corpusbased evidence of actual teacher behaviour with respect to the teaching of second language (L2 found the duration of pronunciation teaching was not more than $10 \%$ of the total duration in the F2F setting after four times observations. Those findings observed both pronunciation accuracy and fluency. Furthermore, Huensch (2018) found that $82 \%$ of the participants were taught pronunciation for 15 minutes or less every week or only $5 \%$ of the duration. So, it can be concluded that the teachers neglected pronunciation practice both in F2F and
ERT as pronunciation still received little attention in the teaching practice.

The second finding is the strategy used by the teacher. The findings show that Joy and Mark applied corrective feedback and minimal pairs in the speaking activities in their classes. Besides that, Joy also applied reading and listen-and-repeat as pronunciation training to her students. Joy emphasized pronunciation accuracy features: intonation, stress, and sound when she applied to listen and repeat. However, when she applied corrective feedback as the strategy to train pronunciation accuracy, she emphasized only individual sounds. In Joy classes, she gave pronunciation practice in the synchronous meeting and the asynchronous meeting. Similarly, Mark, who implemented corrective feedback to teach pronunciation, highlighted vowel and consonant sounds. Both Joy and Mark used minimal pairs as the feedback to show the correct pronunciation of the student's mistake.

This result is in line with Rahayu and Munir (2018) study. It was found that the teachers applied reading aloud, listen-and-repeat, and corrective feedback as the strategy. Differently, the teachers in their study teach pronunciation in all meetings, no matter what materials they taught. Previous research indicated that reading aloud and minimal pairs use are classified explicitly as preferred activities or reported as frequently used (Burgessa and Spencer 2000; Hismanoglu and Hismanoglu 2010). In line with the findings of previous studies in various settings (Chiu 2008; Darcy, Ewert, and Lidster 2012; Jennifer A. Foote, Holtby, and Derwing 2012; Jennifer Ann Foote et al. 2016; Murphy 2011; Wahid and Sulong 2013), this study shows that 
pronunciation instruction relies on error correction through corrective feedback. Lyster, Saito, and Sato (2013) and Saito and Lyster (2012) have found that corrective feedback is effective for language improvement in learners.

The findings in this study partially confirm and reject earlier results reported by Shah, Othman, and Senom (2017) in terms of focus on pronunciation teaching. Shah, Othman, and Senom (2017) found that through observation, the English teachers observed did not focus and emphasize any specific pronunciation features during lessons in the classroom. Furthermore, the teaching did not focus on only suprasegmental or segmental aspects of pronunciation. It is because the focus of pronunciation teaching is determined by what the learners need. In contrast, this present study showed that the pronunciation teaching clearly focused on the suprasegmental aspect but with an uncertain focus for each lesson. Also, the teaching was based on teachers' initiative instead of students' needs.

\section{Challenges in Pronunciation Teaching During ERT}

The non-participatory observation, questionnaire, and in-depth interview applied to the research participants showed the teachers' challenges in teaching pronunciation during ERT. The challenges could be from the students, media, and the teacher themselves.

\section{Internet connection}

The gathered data from observation during the teaching and learning process showed that Joy's problems are primarily due to poor internet connection. It is because not all of the students' residences are within the range of the internet signal. Joy admitted that she should always think about what media she is supposed to use and manage when she could use that to minimize the students' burden. In addition, she claimed that in the synchronous mode, there was a time lag between her pronunciation example and students' responses. Mark also admitted that poor internet connection sometimes took a long time to conduct the learning process. Due to that condition, he asked his students to turn off their cameras to minimize the internet access quota. In consequence, he could not see and ensure whether all his students practiced pronunciation or not.

This study found the same results as the findings of other researchers investigating the problem of teaching pronunciation during ERT. A qualitative study done in India identified that poor internet access is the biggest challenge of distance language teaching (Hasan and Khan 2020). In developing countries like Malaysia, unsatisfactory internet access disrupts study time, and learning needs to be extended from the actual school period (Yusuf and Ahmad 2020). In Ghana, most students do not have an adequate learning environment and good internet access (Owusu-Fordjour, Koomson, and Hanson 2020). Moreover, to deal with learning problems related to a poor internet connection, countries worldwide have used different ways of online learning. For instance, based on the research done by Drane, Vernon, and O'Shea (2020), New Zealand has adopted a combined approach of using television channels to deliver educational content integrated with internet delivery and hard copy curriculum resources. In Queensland, Australia, television has 
been used to involve parents and help their children study due to poor internet connection. In Portugal, a partnership between schools and the postal service helped deliver printer learning resources immediately delivered to the students' homes. From the students' perspective, the technical requirements are also the most significant disadvantage of conducting ERT. For several families, providing device equipment with cameras, microphones, and good internet connection for their children to study and parents to teach or work is impossible (Nenakhova 2021).

\section{Student's motivation and engagement}

The teachers have to be as creative as possible to design learning materials and media to increase students' motivation and engagement. Joy said that she has tried teaching approaches to know which one is suitable to get student's attention and increase their engagement. For example, she found that her students like to learn pronunciation from interactive audio and videos. Similarly, Mark carried out speaking for enjoyment activity during synchronous meetings to increase students' willingness to do speaking in English. This method was applied because while evaluating the student's speaking, he was ignored, and no response from the students.

This study produced results that corroborate the findings of a great deal of the previous work in this field. Yi and Jang (2020) also confirmed the same finding, who researched in South Korea. The study presented how English teachers reshaped their teaching practices and experiences in ERT during the pandemic. They considered a purposeful and effective use of their second language, developed lesson plans with more frequent linguistic and cultural negotiations, and took on more roles to design lessons, for example, a video creator. In Arab countries, the language teachers revealed that they faced problems in the virtual context when preparing learning materials and implementing the learning strategies they used in traditional teaching and learning (F2F learning), which becomes insufficient during ERT (Hazaea, Bin-Hady, and Toujani 2020).

\section{Time management}

The time duration per lesson hours in ERT is shorter than during F2F. It is only 30 minutes per lesson hour in ERT, while in F2F, it is 45 minutes. In other words, the learning materials delivered are lesser than in F2F learning, but the time consuming is longer than in F2F. As said by Joy, the teachers have to be selective in selecting learning materials and manage the time when they are supposed to deliver the materials. Joy and Mark stated the opening session, which normally only takes 5-10 minutes, could be up to 30 minutes during ERT only to check students' attendance and make sure all of them are ready to study. Joy and Mark claimed that their students tend to be more undisciplined in attending classes during ERT compared to F2F on the students' side. They admitted that their students might have been bored with distance learning since there was no learning atmosphere at their homes.

The current study's findings are consistent with Zhang's (2020) result of study which revealed that teachers experienced time management problems teaching in distance teaching mode. In addition, some of them encountered online interaction problems while the others faced strategies issues in

\section{8}


online interactive, monitoring students learning, and engaging students in learning.

\section{Pronunciation assessment}

- The absence of pronunciation rubric assessment

Having a specific assessment rubric would help the teachers in grading more consistently and objectively. For example, in students' pronunciation assessment, Joy and Mark graded their students' pronunciation without using pronunciation rubric assessment. Joy claimed that she still could not find the suitable one as the guidance in assessing pronunciation. All this time, she used a speaking assessment rubric that does not clearly describe the aspects of pronunciation that must be assessed. On the other hand, Mark admitted that he did not know what would be assessed from pronunciation. He scored the students' pronunciation based on many mispronunciations and cannot be understood, lots of mistakes but still understandable, few mistakes, and no mistakes at all.

The present findings seem to be consistent with other research which found the unavailability of an appropriate pronunciation assessment rubric. Speaking rubrics are the only resource that educators and learners have for measuring pronunciation effects for most speaking tests, which may or may not even mention pronunciation features in them. Even the rubrics of well-known tests such as the Test of English as a Foreign Language (TOEFL) do not include detailed pronunciation descriptors. This fact almost proves that pronunciation will be a hidden factor and a source of unsystematic variation in assessments and examinations (Levis 2006).

- A large number of students

In one class, the number of students ranged between 30-32 students. With those numbers and the learning duration only 30 minutes per lesson hours, the teachers faced difficulties managing the time when they wanted to evaluate students' pronunciation. Joy assessed her students' pronunciation asynchronously by giving assignments. Her students practiced and recorded their pronunciation by themselves, and then Joy scored the recordings one by one. She claimed that this way of assessment is the best way to save time. However, it is an ineffective way to provide feedback. In addition, she also carried out the pronunciation and speaking evaluation simultaneously via WhatsApp Video Call. This kind of evaluation took much time, and she could not finish evaluating all of the students even though they were divided into groups.

This finding agrees with Asikin and Ibrahim (2020) and Darcy, Ewert, and Lidster (2012) findings that showed the class size could also be challenging, with a large number of students making it impossible for the teacher to evaluate every student's pronunciation ability. Therefore, teaching and evaluating pronunciation in a short period can be very challenging for teachers. Moreover, Zhang (2020) confirmed that the participants in his research struggled to do pronunciation assessment because they 
did not find effective ways to conduct a wholeclass assessment. The teachers also did not find suitable ways to create direct interaction and communication with students due to the lack of time in ERT and a large number of students.

\section{CONCLUSION}

The present study was designed to investigate pronunciation accuracy practice in an ERT setting. From the findings, the conclusions are as follows: (1) the duration and portion of pronunciation accuracy instruction during ERT is $11 \%$ of the total duration of lesson hours; (2) the most used strategy is corrective feedback as the response of students' mispronounce and stress is the least attention among three pronunciation accuracy features, also the teachers faced challenges in conducting teaching and evaluating students' pronunciation, which are a terrible internet connection, students' motivation and engagement, time management, the unavailability of pronunciation rubric assessment, and a large number of students in one class.

\section{REFERENCES}

Abdolmanafi-Rokni, Seyed Jalal, Seyed Jalal, and Abdolmanafi - Rokni. 2013. "The Effect of Listening to Audio Stories on Pronunciation of EFL Learners." MJAL Journal.

Asikin, Norbazila Mohd, and Noor Aireen Ibrahim. 2020. "Challenges in Teaching Pronunciation in Malaysian Secondary Schools: Novice Teacher's Perspective." LSP International Journal 7 (2): 11937. https://doi.org/10.11113/lspi.v7.16349.

Baker, Amanda, and John Murphy. 2011. "Knowledge Base of Pronunciation Teaching: Staking Out the Territory." TESL Canada Journal. https://doi. org/10.18806/tesl.v28i2.1071.
Brown, Adam. 1991. Pronunciation Models. London: NUS Press.

Burgessa, John, and Sheila Spencer. 2000. "Phonology and Pronunciation in Integrated Language Teaching and Teacher Education." System 28 (2): 191-215. https://doi.org/10.1016/S0346$251 \mathrm{X}(00) 00007-5$.

Celce-Murcia, Marianne, Donna M. Brinton, and Janet M. Goodwin. 1996. Teaching Pronunciation: A Reference for Teachers of English to Speakers of Other Languages. TESOL Quarterly. Cambridge, England: Cambridge University Press. https://doi. org/10.2307/3588013.

Chiu, Hsing-Hui Winnie. 2008. "Practical Understandings: Teachers' Beliefs and Practices in Pronunciation Teaching." THE UNIVERSITY OF TEXAS AT ARLINGTON. https://rc.library.uta. edu/uta-ir/bitstream/handle/10106/1651/Chiu_ uta_2502M_10027.pdf?sequence=1\&isAllowed=y.

Couper, Graeme. 2016. “Teacher Cognition of Pronunciation Teaching amongst English Language Teachers in Uruguay." Journal of Second Language Pronunciation. https://doi.org/10.1075/jslp.2.1.02cou.

Cunningham, Una. 2015. "Teaching English Pronunciation Online to Swedish Primary-School Teachers." Second Language Learning and Teaching 24. https:// doi.org/10.1007/978-3-319-11092-9_4.

Darcy, Isabelle, Doreen Ewert, and Ryan Lidster. 2012. "Bringing Pronunciation Instruction Back into the Classroom: An ESL Teachers' Pronunciation "Toolbox." Proceedings of the 3rd Pronunciation in Second Language Learning and Teaching Conference.

Derwing, Tracey M., and Murray J. Munro. 2005. "Second Language Accent and Pronunciation Teaching: A Research-Based Approach." TESOL Quarterly 39 (3): 379. https://doi.org/doi:10.2307/3588486.

Derwing, Tracey M., Murray J. Munro, and Grace Wiebe. 1998. "Evidence in Favor of a Broad Framework for Pronunciation Instruction." Language Learning 48 (3): 393-410. https://doi.org/https://doi. org/10.1111/0023-8333.00047.

Drane, Catherine, Lynette Vernon, and Sarah O'Shea. 
2020. "The Impact of 'Learning at Home' on the Educational Outcomes of Vulnerable Children in Australia during the COVID-19 Pandemic;" In Literature Review Prepared by the National Centre for Student Equity in Higher Education, Curtin University, Australia., 1-15.

Foote, Jennifer A., Amy K. Holtby, and Tracey M. Derwing. 2012. "Survey of the Teaching of Pronunciation in Adult ESL Programs in Canada, 2010." TESL Canada Journal. https://doi.org/10.18806/ tesl.v29i1.1086.

Foote, Jennifer Ann, Pavel Trofimovich, Laura Collins, and Fernanda Soler Urzúa. 2016. "Pronunciation Teaching Practices in Communicative Second Language Classes." Language Learning Journal 44 (2): 181-96. https://doi.org/10.1080/09571736.2013 .784345 .

Gilakjani, Abbas Pourhosein, Reihaneh Sheikhy, Iraj Montashery, and Iraj Montashery. 2019. "A Mixed Method Study of Teachers' Attitudes towards Computer Pronunciation Software in Teaching English Pronunciation." International Journal of Instruction 12 (1): 821-40. https://doi.org/10.29333/ iji.2019.12153a.

Gilakjani, Abbas Pourhossein. 2017. "English Pronunciation Instruction: Views and Recommendations." Journal of Language Teaching and Research 8 (6): 1249-55. https://doi.org/http://dx.doi. org/10.17507/jltr.0806.30.

Hasan, Naziya, and Naved Hassan Khan. 2020. "ONLINE TEACHING-LEARNING DURING COVID-19 PANDEMIC: STUDENTS' PERSPECTIVE." The Online Journal of Distance Education and E-Learning 8 (4).

Hazaea, Abduljalil Nasr, Wagdi Rashad Ali Bin-Hady, and Marwa Mekni Toujani. 2020. "Emergency Remote English Language Teaching in the Arab League Countries: Challenges and Remedies." Computer-Assisted Language Learning Electronic Journal(CALL-EJ) 22 (1): 201-22.

Hazaymeh, Wafa' A. 2021. 'EFL Students' Perceptions of Online Distance Learning for Enhancing English Language Learning During Covid-19 Pandemic." International Journal of Instruction 14 (3): 501-18. https://doi.org/10.29333/iji.2021.14329a.

Hismanoglu, Murat, and Sibel Hismanoglu. 2010. "Language Teachers' Preferences of Pronunciation Teaching Techniques: Traditional or Modern?" Procedia - Social and Behavioral Sciences 2 (2): 983-89.

Hodges, Charles B, and Denver J Fowler. 2020. "The COVID-19 Crisis and Faculty Members in Higher Education: From Emergency Remote Teaching to Better Teaching through Reflection." International Journal of Multidisciplinary Perspectives in Higher Education.

Huensch, Amanda. 2018. "Pronunciation in Foreign Language Classrooms: Instructors' Training, Classroom Practices, and Beliefs." Pronunciation in Foreign Language Classrooms: Instructors' Training, Classroom Practices, and Beliefs 1 (20). https://doi. org/10.1177/1362168818767182.

Kelly, Gerald. 2002. How to Teach Pronunciation. Harlow: Longman.

Levis, John M. 2006. "Pronunciation and the Assessment of Spoken Language." Spoken English, Tesol and Applied Linguistics, 245-70. https://doi. org/10.1057/9780230584587_11.

Lyster, Roy, Kazuya Saito, and Masatoshi Sato. 2013. "Oral Corrective Feedback in Second Language Classrooms." Language Teaching 46 (1): 1-40.

Mardiah, Henny. 2020. "The Use of E-Learning to Teach English in the Time of the Covid-19 Pandemic." English Teaching and Linguistics Journal (ETLiJ). https://doi.org/10.30596/etlij.v1i2.4894.

Martin, Ines A. 2020. "Pronunciation Development and Instruction in Distance Language Learning." Language Learning and Technology. https://doi. org/10.125/44711.

Miles, Matthew B., A. Michael Huberman, and Johnny Saldaña. 2014. Qualitative Data Analysis: A Methods Sourcebook. 3rd ed. London: Sage Publications, Inc.

Murphy, Deirdre. 2011. "An Investigation of English Pronunciation Teaching in Ireland." English Today. https://doi.org/10.1017/s0266078411000484. 
Nenakhova, Ekaterina. 2021. "Distance Learning Practices on the Example of Second Language Learning during Coronavirus Epidemic in Russia." International Journal of Instruction 14 (3): 807-26. https:// doi.org/10.29333/iji.2021.14347a.

Owusu-Fordjour, C., C. K. Koomson, and D. Hanson. 2020. "The Impact of Covid-19 on Learning - The Perspective of the Ghanaian Student." European Journal of Education Studies 7 (3). https://doi. org/10.5281/zenodo.3753586.

Pennington, Martha C., and Jack C. Richards. 1986. "Pronunciation Revisited." TESOL Quarterly. https://doi.org/10.2307/3586541.

Rahayu, Alfi Septi, and Ahmad Munir. 2018. "A Case Study of The Pronunciation Practice in A Senior High School.” RETAIN 6 (2): 104-11.

Saito, Kazuya, and Roy Lyster. 2012. "Investigating the Pedagogical Potential of Recasts for L2 Vowel Acquisition.” TESOL Quarterly 46 (2).

Shah, Shanina Sharatol Ahmad, Juliana Othman, and Fatiha Senom. 2017. "The Pronunciation Component in ESL Lessons: Teachers' Beliefs and Practices." Indonesian Journal of Applied Linguistics 6 (2): 193-203. https://doi.org/10.17509/ijal.v6i2.4844.

Thomson, Ron I., and Tracey M. Derwing. 2015. "The Effectiveness of L2 Pronunciation Instruction: A
Narrative Review." Applied Linguistics 36 (3): 32644. https://doi.org/10.1093/applin/amu076.

Wahid, Ridwan, and Suhaila Sulong. 2013. "The Gap between Research and Practice in the Teaching of English Pronunciation: Insights from Teachers' Beliefs and Practices." World Applied Sciences Journal 21 (Special Issue of Studies in Language Teaching and Learning), 133-42.

Yi, Youngjoo, and Jinsil Jang. 2020. "Envisioning Possibilities amid the COVID-19 Pandemic: Implications from English Language Teaching in South Korea." TESOL Journal 11 (3). https://doi. org/10.1002/tesj.543.

Yoshida, Marla. 2016. Beyond Repeat After Me: Teaching Pronunciation To Ells. TESOL Press.

Yusuf, Bibi Noraini Mohd, and Jihan Ahmad. 2020. "Are We Prepared Enough? A Case Study Of Challenges In Online Learning In A Private Higher Learning Institution During The Covid-19 Outbreaks." Advances in Social Sciences Research Journal 7 (5). https://doi.org/10.14738/assrj.75.8211.

Zhang, Tianhong. 2020. "Learning from the Emergency Remote Teaching-Learning in China When Primary and Secondary Schools Were Disrupted by COVID-19 Pandemic." Education Faculty Publications. https://doi.org/10.21203/rs.3.rs-40889/v1. 